Л. Г. Зайончик та ін. - К. : Кондор, 2011. 392 c.

4. Орловська, О. В. Комплексний розвиток продуктивних сил Карпатського регіону / дис. ... канд. ек. наук: 08.00.05 К., 2007. - 148 c.

5. Таньков, К. М. Виробнича логістика : навч. посіб. / К. М. Таньков, О. М. Тридід, Т. О. Колодязєва. - Х. : ВД «IНЖЕК», 2004. - 352 c.

6. Николаева, М. А. Товароведение потребительских товаров. Теоретические основы : учеб. для вузов / М. А. Николаева. - M. : HOPMA, 2000. -283 c.

7. Транспорт і зв'язок України -2012 : статистичний зб. - К., 2013. - 269 с.

DOI 10.18664/338.47:338.45.v0i64.149570
8. Омельченко, О. Д. Створення логістичної системи керування вантажопотоками на залізничному транспорті [Текст] / О. Д. Омельченко,С. О. Артем-чук // Зб. наук. пр. ДЕТУТ. Сер. Транспортні системи і технології. - 2007. Вип. 12. - С. 141-145.

9. Пономарьова, Ю. В. Логістика [Текст]: навч. посіб. / Ю. В. Пономарьова. К.: Центр навчальної літератури, 2003. $192 \mathrm{c}$.

10. Тридід, О. М. Логістика [Текст]: навч. посіб. / О. М. Тридід.- К. : Знання, 2008. - 566 с

УДК 656.2.001.73(477)

\title{
СТАН І ОНОВЛЕННЯ РУХОМОГО СКЛАДУ В УМОВАХ РЕФОРМУВАННЯ УКРЗАЛІЗНИЦ
}

\author{
Єлагін Ю.В., к.е.н., доцент, \\ Глущенко Ю.В., махістр, \\ Цапко Л.В., магістр (УкрДУЗТ)
}

Визначено поточний стан рухомого складу та особливості різних напрямів його оновлення. Набагато більшою проблемою порівняно з дефіцитом вагонів являється дефіцит локомотивів. Прискорене оновлення та поповнення тягового рухомого складумпотрібно усім ключовим галузям економіки Украӥни. Для иього потрібна участь в оновленні локомотивного парку приватних операторів перевізників.

Ключові слова: локомотиви,оновлення тягового рухомого складу

\section{СОСТОЯНИЕ И ОБНОВЛЕНИЕ ПОДВИЖНОГО СОСТАВА В УСЛОВИЯХ РЕФОРМИРОВАНИЯ УКРЗАЛИЗНЫЦИ}

\author{
Елагин Ю.В., к.э.н., доцент, \\ Глущенко Ю.В., магистр, \\ Цапко Л.В., магистр (УкрГУЖТ)
}

Рассмотрено текущее состояние подвижного состава и основные особенности разных направлений его обновления. Намного большей проблемой сравнительно с дефицитом вагонов является дефицит локомотивов. Ускоренное обновление и пополнение тягового подвижного состава, необходимо всем ключевым отраслям 
экономики Украинь. Для этого необходимо участие в обновлении локомотивного парка частных операторов.

Ключевые слова: локомотивы,обновление тягового подвижного состава

\title{
STATE AND REPLENISHMENT OF THE ROLLING STOCK IN CONDITIONS OF UKRZALIZNYTSIA REFORM
}

\author{
Elagin Y.V., Ph. D., associate Professor, \\ HlushchenkoY.V., Master Degree, \\ Tsapko L.V., Master Degree (USURT)
}

The article is devoted to the analysis of the current state and features of the updating process of the Ukrzaliznytsia rolling stock. The article defines the current state of rolling stock and the main features of various directions of its updating and replenishment in accordance with the demand and opportunities of the economy. Regarding to rolling stock, the situation with replenishment and renewal of wagons is significantly improving. Own fleets of freight wagons are replenished by "Ukrzaliznytsya" as well as private cargo owners who use them. Comparing to the problem of shortage of wagons, the shortage of freight and electric locomotives is more important. At present, the technical condition of locomotives is characterized by ever-increasing operating costs and low profitability compared to the rolling stock of the new generation. An accelerated renewal and replenishment of rolling stock, primarily traction, is required for all key sectors of the economy and the Ukrainian society in general. All this requires not only the use of the country's resources and Ukrzaliznytsia, but also the creation of conditions, mechanisms and regulations of participation in updating the locomotives, transportation of other participants except Ukrzaliznytsia, including private ones. There is a need for such an organizational and legal framework in which private capital will be interested in cooperation with the state as well as the state will benefit from cooperation with private investors. It is Important and topical issue of the establishment of the production of freight electric locomotives in Ukraine.

Key words: rolling stock, locomotives, electric locomotives, diesel locomotives, renewal of traction rolling stock, private capital, key sectors of economy.

Постановка проблеми. За останні три роки суттєво погіршились основні експлуатаційні показники роботи залізничного транспорту : вантажообіг, обсяг транзитних перевезень, обіг вагону, середньодобова продуктивність вагону, простій на одній технічні станції, середньодобова продуктивність локомотиву, середньодобовий пробіг локомотиву.

В основному це відбувається унаслідок дефіциту тягового рухомого складу. Останніми роками парк вантажних локомотивів неухильно скорочувався. За оцінками фахівців, дефіцит локомотивів "Укрзалізниці" перевищує сто одиниць. На сьогодні на 100 кілометрів залізничної колії в Україні доводиться 2,5-3 локомотиви, коли в сусідній Польщі цей показник більш ніж в три рази вище - 9,4. За даними департаменту локомотивного господарства УЗ, вже до 2020 року залізична галузь буде мати дефіцит магістральних електровозів і тепловозів в об'ємі 440 одиниць, або близько $40 \%$ робочого поточного парку.

Аналіз останніх досліджень $\boldsymbol{i}$ публікацій та виділення невирішених частин загальної проблеми. Вагоме значення для сучасної науки при розв'язанні проблем реформування залізничної галузі та іiї адаптації до роботи в ринковому середовищі мають праці: Ю. С. Бараша[1], О. М. Гненного[2],

Вісник економіки транспорту і промисловості № 64, 2018 
В. Л. Диканя[3], М. В. Макаренка[7] та інших. В той же час проблема оновлення тягового рухомого складу залишається актуальною i потребує потребує вирішення.

Формулювання цілей статmі (постановка завдання). Метою статті $\epsilon$ визначення поточного стану тягового рухомого складу та оптимальних напрямів його оновлення відповідно до потреб та можливостей економіки.

Виклад основного матеріалу. Офіційна статистика по перевезеннях вантажів надається Міністерством інфраструктури в розрізі 18 -ти товарних статей, проте у підсумку вони представляють кінцеві продукти і складові для виробництва всього чотирьох основних галузей, які формують 90\% попиту на залізничні перевезення. Так, кокс i залізна руда - це внутрішнє транспортування до заводів по виплавці чорних металів i продуктів 3 них. Аналогічно, хімічні і мінеральні добрива використовуються при виробництві зернових, а цемент і мінеральні будівельні матеріали - у будівництві. Таким чином, увесь вантажообіг залізницею ділиться на чотири основні галузі: енергетику, сільське господарство, металургію і будівництво. На інші галузі доводиться всього 33,14 млн тонн або 9,7\% від загального обсягу перевезень у 2017 році.

Ключові галузі української промисловості - гірничо-металургійний комплекс, енергетика, виробництво будматеріалів, а також аграрний сектор сильно залежать від залізниці, яка $є$ для них основним, a часто i безальтернативним перевізником. За показниками 2017 року «Укрзалізниця» не забезпечила вивіз більш ніж 25\% вантажів цих галузей. Це блокує реалізацію продукції, викликає нестачу обігових коштів, затоварювання складів, зростання логістичних витрат а подекуди i припинення виробництва.

Наприклад у червні 2018 року проблеми 3 нестачею тягового рухомого складу "Укрзалізниці" привели до масових простоїв вантажних вагонів. Цього разу знерухомими виявилися вагони з вугіллям для теплоелектростанцій. Причому найбільш критична ситуація 3 рухомим складом склалася на Львівській залізниці, де 344 електровозів працювали не більше 27-28 електровозів. Також залізниці щодня бракувало 18-24 магістральних тепловозів. У напрямі Маріуполя кількість потягів на ділянці Очерет-Зоря Волноваха знизилася з 21,3 пар потягів у березні до 19,3 пар в червні. При цьому знизилася і кількість вагонів в кожному складі в середньому на 7 одиниць. В результаті Маріупольський металургійний комбінат ім. Ілліча в червні був вимушений знизити обсяги виробництва чавуну на 25 тис. тонн.

Вже на даний момент "Укрзалізниця" не в змозі забезпечити до $20 \%$ попиту на перевезення зернових, змушуючи аграріїв користуватися послугами автоперевізників, середній тариф яких в 5-10 разів вище, чим пропонує "Уз". Так, 3 41,8 млн тонн експорту зернових в 2017-му році "Укрзалізницею" було доставлено до портів всього 31,2 млн тонн або 74,6\%. 10,3 млн тонн, які залишилися за вирахуванням річкових перевезень, - було доставлено по автомагістралях, які, не призначені для вантажних перевезень в таких масштабах.

Це відбувається унаслідок дефіциту провозної спроможності «Укрзалізниці», в основному тягового рухомого складу .

Що стосується вагонного рухомого складу, то ситуація 3 поповненням i оновленням вагонів помітно покращується. Власні парки вантажних вагонів поповнюють як «Укрзалізниця», так i приватні вантажовласники, які їх використовують.

Згідно з даними Державної служби статистики України, за 2017 рік вагонобудівні підприємства виробили 6831 вагон, що в 2,4 рази більше, ніж в 2016 році. При цьому в 2016 році, коли було вироблено 2811 вагонів, зростання склало 2,5 рази в порівнянні з 2015 роком. 
Що стосується вагонного парку «Укрзалізниці», то за даними департаменту комерційної роботи «УЗ» якщо у 2016 році на власних потужностях було побудовано 370 найбільш затребуваних для перевезень піввагонів, то вже у 2017 році на власних потужностях було побудовано 2606 піввагонів та 115 вагонів було закуплено у сторонніх виробників: 50 піввагонів у Попаснянського ВР3 і 65 фітингових платформ у "Дніпровагонмашу". А у першому кварталі 2018 року потужностях було побудовано 805 піввагонів. Згідно 3 фінансовим планом на 2018-й рік, "Уз" збирається придбати 7050 піввагонів, 3 яких 3600 виробити на власних потужностях, а також придбати 3450 піввагони, 100 фитінгові платформи для перевезень вантажних контейнерів і 137 зерновозів.

Станом на жовтень 2018 року на залізницях України використовувались 64 тис. вантажних вагонів власності «УЗ», 65 тис. вагонів парку українських приватних компаній та ще 3 тис. вагонів компаній інших краін.

\section{Найбільше}

підприємство України ArcelorMittalКривий Ріг придбало у 2018 році 500 вагонів. За даними Полтавського ГОК(Ferrexpo), незважаючи на те, що на даний момент Ferrexpo було закуплено близько 2250 вагонів, різке збільшення часу обороту вагонів не дозволяє своєчасно відвантажувати продукцію, частина якої залишається на складі і зараз на складах майже 300 тис. тонн окатишів, які не вивозяться.

Постійне погіршення тягових потужностей відображається в зниженні продуктивності використання вагонного парку, вимірюваній як середній період обороту вантажного вагону. 3 2003-го року цей показник погіршився з 5,2 до 9,6 діб. Відповідно, впала на 41,4\% ефективність використання вагонів. Тож очевидно, що набагато більшою проблемою порівняно 3 дефіцитом вагонів являється дефіцит локомотивів.
На сьогодні технічний стан локомотивів характеризується постійно зростаючими експлуатаційними витратами та має низьку економічність порівняно 3 рухомим складом нового покоління.

Середній знос парку локомотивів «Укрзалізниці» становить 96,8\%. В тому числі, електровозів - 93,3\%, тепловозів магістральних - 99,6\%, тепловозів маневрових - 99,9\%. Середній вік електровозів складає 40,6 років при нормі 30 років, магістральних тепловозів - 37 років при нормативному 20 років, маневрових тепловозів - 35,8 років при нормі 25 років.

У порівнянні з 2017 роком станом на вересень 2018 року кількість локомотивів зменшилася на 280 одиниці в тому числі магістральних електровозів на 92 одиниці і тепловозів на 18 одиниць, маневрових тепловозів на 170 од. Всього на станом на вересень 2018 року інвентарний парк «Укрзалізниці» нараховує 3566 одиниць локомотивів, 3 яких: пасажирські 550 одиниць (71 теплово3 та 479 електровозів); 1758 вантажні (609 тепловози та 1149 електровози); та 1258 маневрові тепловози.

3 усієї кількості локомотивів інвентарного парку у експлуатації знаходяться 287 пасажирськіх локомотивів, вантажних тепловозів- 202 од., вантажних електровозів - 743 одиниці. В той же час IMF Group Ukraine y дослідженні [8] наводить ще нижчі дані по практичному застосуванні локомотивів на коліях «Укрзалізниці».

При цьому, 3 огляду на зношеність локомотивів в наступні п'ять років вони будуть вибувати 3 ладу прискореними темпами. На теперішній час навіть 3 урахуванням вже підписаного контракту на поставку перших 30 локомотивів General Electric, сумарна кількість робочих локомотивів «Укрзалізниці», призначених для вантажних перевезень становить сьогодні всього 579 одиниць і щорічно скорочується в середньому на $4,4 \%$ або 25 локомотивів. Так, якщо припустити, що в наступні п'ять років темпи вибуття

Вісник економіки транспорту і промисловості № 64, 2018 
локомотивного складу зберігатимуться на рівні 2012-2017 років, то при збереженні поточних показників їх продуктивності і вибування - до 2022-го року у «УЗ» залишиться всього 504 локомотива, здатних перевозити по 0,58 млн тонн на рік. Тобто, загальний обсяг річних потужностей «Укрзалізниці» по вантажообігу складе всього 291 млн тонн на рік [8].

Зважаючи на високий ступінь зносу виробничих засобів, ключовим напрямом забезпечення перевезень та відповідно виконання завдань реформування галузі $\epsilon$ техніко-технологічне оновлення засобів перевезень та їх обслуговування i, насамперед, рухомого складу [4].

Згідно 3 офіційним прогнозом МВФ, до 2022-го року реальний ВВП України зросте до 1195 млрд грн (в цінах 2010 року) або на 19,6\%. Очевидно, що слідом за обсягом реального ВВП зростатиме i попит на вантажні перевезення залізницею. Якщо побудувати кореляційну модель на основі даних за 2008-2017 роки, то можна побачити, що зростання реального ВВП на 1млрд грн супроводжується приростом вантажообігу залізницею в середньому на 0,59 млн т. Відповідно зросте і потреба у локомотивах і вагонах.

Таким чином термінове оновлення та поповнення рухомого складу, в першу чергу тягового, потрібно усім ключовим галузям економіки і взагалі суспільству України.

Одже виникає необхідність визначити перспективи i шляхи оновлення, насамперед, тягового рухомого складу.

Перший напрям поповнення локомотивного парку,найбільш цікавий для економіки в цілому - це організація виробництва у середені країни. За останні роки при потужній державній підтримці практично з нуля побудований ряд великих підприємств : спільне 3 General Electric (США) по виробництву тепловозів в Казахстані; з Siemens (Німеччина) - в Росії. Показовим є досвід Казахстану, якому за останні 7 років вдалося зменшити знос локомотивів з 77\% до 55\%. Знос тягового рухомого складу в Росії - 62\%. На наш погляд стосовно організації виробництва тепловозів в Україні, час втрачено: поперше організовувати виробництво в країні, маючи власні виробничі потужності у суміжних країнах економічно не доцільно, а по-друге це обумовлено втратою потужностей підприємства "Лугансктепловоз", а також неможливістю чекати ще 4-5 років, для організації виробництва. А от стосовно виробництва електровозів, стан яких дещо кращий, у України ще $\epsilon$ 4-5 років, відповідні профільні підприємства i, відповідно, перспективи налагодження виробництва електровозів.

Другий напрям поповнення тягового рухомого складу - закупівля нових локомотивів. Вони є ефективнішими і розраховані на тривалішу експлуатацію, ніж модернізовані старі машини. Цей шлях на сьогодні і обрала «Укрзалізниця». Для оновлення рухомого складу «Укрзалізниця» склала спеціальну Стратегію розвитку залізниць на 2017-2021 роки. Згідно зі Стратегією, до 2021 року залізниці мали отримати 52 вантажних тепловозів, 170 електровозів, 3 яких: 10 двосистемних пасажирських, 75 вантажних змінного струму, 85 вантажних постійного струму, 40 двосистемних грузових, на покупку яких повинні були витратити 150 мільярдів гривень.

Але на кінець 2017 року ця стратегія була переглянута і станом на 2018-2019pр. реалізується купівля перших 30 тепловозів GE, 5 вантажних електровозів та ведуться переговори про співробітництво зі світовими компаніями Alstom та CRRC, мета яких до кінця 2018 року визначитися із стратегічним партнером 3 виробництва електровозів. Потреби «Укрзалізниці» придбати не менше 200 локомотивів упродовж наступних семи років, а до 2029 року - до 500 нових електровозів.

Цей напрям оновлення найбільш ефективний, коли закупівлі здійснюються 
за власні кошти - У випадку, як із тепловозами GE, поставки яких здійснюються на умовах фінансового лізінгу, їх вартість зростає на 15-30\% за рахунок економічних витрат та інтересів лізінгодавця.

Наступний напрям поповнення парку тягового рухомого складу полягає у допуску до перевезень приватних локомотивів. Лібералізації ринку приватної тяги - це зобов'язання України, які торкаються імплементації європейської моделі залізничного транспорту, яка має на увазі створення конкурентних умов i рівного доступу до інфраструктури приватних перевізників. Європейський залізничний ринок припускає наявність декількох перевізників зі своєю тягою і вагонами на залізниці.

Зараз в Україні дозволено використання приватних вагонів, а приватні локомотиви 3 виходом на магістральні шляхи - це, швидше, виключення. УЗ має можливість навіть без ухвалення законопроекту «Про залізничний транспорт» №7316, який встановлює принципи рівноправного доступу до послуг інфраструктури приватних операторів-перевізників, допустити приватну тягу на свої магістралі. Більше того, такі приклади вже є. На сьогодні розроблені правила технічної експлуатації, в яких передбачено використання приватних локомотивів. Немає тільки затвердженого порядку оборотності рухомого складу, формату реалізації доступу приватної тяги на загальну інфраструктуру, а також часових рамок їі імплементації.

Цей шлях не вимагає від «Укрзалізниці» інвестицій. Але потребує віддати частину монопольних функцій локомотивної роботи іншим операторам. Якщо подивитися на досвід європейських країн, то там вродовж перших 5-7 років допуску приватних перевізників, держоператори втрачали до $30 \%$ свого ринку. Проте ця відносна втрата в умовах зростання ринку та обсягів перевезень,в абсолютному значенні не така значна, а якість перевезень значно зросла за рахунок виникнення конкуренції. До того ж через вище згадані проблеми 3 перевезення вантажів залізничним транспортом в Україні, порівняно з 2017 роком в 2018-му відбувається в середньому приблизно на $4,5 \%$ скорочення об'ємів залізничних перевезень. В той же час автоперевезення показують зростання на 8\%.

Значною проблемою, яку необхідно вирішити при впровадженні приватої тяги $\epsilon$ ліквідація перехресного субсидіювання пасажирських перевезень за рахунок вантажних i створення механізму фінансування збиткових пасажирських перевезень. Перевезення пасажирів залізничним транспортом у внутрішньому i особливо регіональному сполученні $\epsilon$ збитковим видом діяльності. Для його функціонування i розвитку потрібна фінансова підтримка. У тих державах, де припинена практика перехресного субсидування пасажирських перевезень за рахунок вантажних, обов'язково здійснюється фінансова підтримка за рахунок держави. Там, де така підтримка була припинена, суттево зросла вартість квитків, скоротилось оновлення основних фондів, підвищилась кількість аварій, скоротились обсяги перевезень пасажирів [5].

Одже для впровадження приватної локомотивної тяги необхідно розробити механізми і нормативну базу фінансування збиткових пасажирських перевезень та інфраструктури, затвердити правила допуску перевізників до інфраструктури. Спершу можна втілити застосування приватних локомотивів на окремих ділянках залізниці, забезпечивши за допомогою приватної тяги, наприклад, перевезення від конкретного виробника в порт.

I, нарешті, останній напрям поповнення парку тягового рухомого складу, що викликає найбільше недовіри 3 боку приватного бізнесу, це державноприватне партнерство (ДПП). Концепція державно-приватного партнерства являє 
собою альтернативу приватизації життєво важливих об'єктів державної власності, які мають стратегічне значення i застосовується при обмеженості фінансових можливостей держави для розвитку галузей інфраструктури, у тому числі залізничного транспорту.

ДПП полягає у об'єднанні ресурсів і дій держави і приватного сектора в різних формах для забезпечення розширеного відтворення і розвитку галузі .Практичне втілення ДПП може полягати, наприклад, у створенні спільної компанії з використання і управління загальним парком рухомого складу.

Успішне функціонування спільних державно-приватних підприємств досягається за умови, коли державний i приватний сектори можуть спільно забезпечити вигоди, які є недосяжними для кожного з них окремо. Поєднання інтересів держави і приватного капіталу, розподіл ризиків та відповідальності має досить значний спектр варіантів: від виключно державної власності на об'єкт до виключно приватної власності на нього.

Основним чинником, який стримує розвиток державно-приватного партнерства в транспортній галузі України, являється слабка нормативно-правова база. Враховуючи i так достатню зарегульованість транспортної галузі і усі складнощі, пов'язані 3 проходженням бюрократичних процедур, приватний бізнес негативно відноситься до ДПП.

Висновки і пропозиції. Необхідне прискорене оновлення тягового рухомого складу.Для цього вважаємо за потрібне не тільки використання власних ресурсів держави та «Укрзалізниці», а і створення умов, механізмів і регламентів участі в оновленні локомотивного парку, перевезеннях інших учасників крім «Укрзалізниці» у тому числі приватних. Необхідне таке організаційно-правове забезпечення, за якого приватний капітал буде зацікавлений у співробітництві 3 державою, а держава, в свою чергу, отримуватиме переваги від співпраці 3 приватними інвесторами. Важливим актуальним питанням $є$ налагодження в Україні виробництва ватажних електровозів.

\section{ПЕРЕЛІК ВИКОРИСТАНИХ ДЖЕРЕЛ}

1. Бараш Ю. С. Обгрунтування оптимальної моделі управління залізничним транспортом // Залізничний транспорт України, 2005. - №9 - С. 208-213.

2. Гненний О.M. Проблеми оновлення тягового рухомого складу та оцінка ефективності інвестиційних проектів у локомотивному господарстві./ O.М. Гненний, А.В. Вишнякова// Збірник наукових праць Дніпропетровського національного університету залізничного транспорту імені академіка В. Лазаряна «Проблеми економіки транспорту», 2015, вип. 9.- С. 105-112.

3. Дикань В. Л. Особливості реформування Національної транспортної системи, Дикань В. Л., Слагіна О. М., // Вісник економіки транспорту i промисловості, 2002. № 1. С. 17-21.

4. Слагін Ю. В. Реформування Укрзалізниці: стан і особливості. / Слагін Ю.В.,Брильов Д.І., Зубарєва Л.А. // Вісник економіки транспорту і промисловості, 2018. №63 c.??-??.

5. Слагін Ю.В. Реформування i суспільні ефекти пасажирських перевезень залізничної галузі [Текст] / Ю.В. Слагін, Н.O. Проценко // Вісник економіки транспорту i промисловості: збірник наукових праць. - Харків: УкрДУзТ. 2017. - Вип. 58. - С. 96-102.

6. Обруч Г.В. Забезпечення розвитку потенціалу конкурентоспроможності вагонобудівних підприємств України: дис. ... канд. екон. наук: 08.00.04 // Український державний університет залізничного транспорту. Харків, 2017. 265 с.

7. Проблеми та основні напрямки реформування залізничного транспорту України/ Ю. М. Цвєтов, М. В. Макаренко та ін. К. КУЕТТ, 2007. - 222 с.

8. Исследование достаточности объема локомотивных мощностей для

Вісник економіки транспорту і промисловості № 64, 2018 
грузовых перевозок железнодорожным транспортом в условиях роста урожая и восстановления экономики Украины до 2023 года. [Електронний ресурс].- Режим доступу: https: // http://imfgroup.com.ua /ru/2018/07/23/
9. Вопрос времени: Как внедрять частную тягу на железных дорогах Украины [Електронний ресурс].- Режим доступу: https: //cfts.org.ua/articles/ vopros_vremeni_kak_vnedryat_chastnuyu _tyagu_na_zheleznykh_dorogakh_ukrainy_1 374/98979

УДК 339.138:656.2 (477)

\title{
ФОРМУВАННЯ ПОЗИТИВНОГО ІМІДЖУ ЗАЛІЗНИЧНОЇ КОМПАНІї АТ "УКРЗАЛІЗНИЦЯ"
}

\author{
Зоріна O.I., д.е.н., професор, \\ Чернявський А.В., магістр (УкрДУЗТ)
}

B статті запропоновано SWOT - аналіз в якості інструменту визначення ключових факторів, щз знижують конкурентоспроможність пасажирських перевезень на транспортному ринку України. Визначено підходи до покращення діяльності залізничної компанії АT "Укрзалізниия". Розроблено пропозиції по формуванню позитивного іміджу транспортного підприємства в галузі пасажирських перевезень залізнииями. Як наслідок ие покращить сприйняття споживачів про надані, залізничною компанією, послуги.

Ключові слова: Укрзалізниця, SWOT - аналіз, імідж, транспорт, послуги, громадська думка.

\section{ФОРМИРОВАНИЕ ПОЛОЖИТЕЛЬНОГО ИМИДЖА ЖЕЛЕЗНОДОРОЖНОЙ КОМПАНИИ АО "УКРЗАЛИЗНЫЦЯ"}

\author{
Зоріна O.I., д.э.н., професор, \\ Чернявский А.В., магистр (УкрГУжТ)
}

B статье предложен SWOT - анализ в качестве инструмента определения ключевых факторов, снижающих конкурентоспособность пассажсирских перевозок на транспортном рынке Украины. Определень подходыл к улучшению деятельности железнодорожной компании АО "Укрзализныия". Разработаны предложения по формированию положительного имиджа транспортного предприятия в области пассажирских перевозок железными дорогами. В результате это улучшит восприятие потребителей по предоставленим, железнодорожной компанией, услугам.

Ключевые слова: Укрзализныця, SWOT - анализ, имидж, транспорт, услуги, общественное мнение.

(C) Зоріна O.I., Чернявський А.В.
Вісник економіки транспорту і промисловості № 64, 2018 